Justyna Kobus

(Pracownia Dialektologiczna IFP UAM)

dr, jusper@amu.edu.pl

\title{
Archiwum Pracowni Dialektologicznej Uniwersytetu im. Adama Mickiewicza w Poznaniu - historia, organizacja, działalność
}

Niniejszy artykuł jest opisem zasobu oraz funkcjonowania na przestrzeni lat (z naciskiem na ostatnie dziesięciolecie) archiwum Pracowni Dialektologicznej UAM (dalej także: PD UAM) ${ }^{1}$.

Archiwum Pracowni Dialektologicznej Uniwersytetu im. Adama Mickiewicza w Poznaniu obchodzi w tym roku 70. rocznicę swojego istnienia.

Placówka ta jest mało znana, a jej zasób był gromadzony i powiększany w zależności od aktualnych problemów - bądź to z myślą o pilnej potrzebie archiwizacji (okres powojenny), bądź w celach stricte badawczych (tzw. okres atlasowy ${ }^{2}$ ). Od kilkunastu lat działalność archiwum jest skorelowana z aktualnymi trendami naukowymi - wychodzeniem poza mury uczelni oraz podporządkowana głównemu założeniu (od początku istnienia), czyli archiwizacji fonograficznej mowy ludowej (obecnie języka mieszkańców wsi³).

\footnotetext{
${ }^{1}$ Artykuł jest przeredagowaną $\mathrm{w}$ niewielkim stopniu pracą dyplomową, którą napisałam w ramach Studi-ów Podyplomowych Archiwistyki i Zarządzania Dokumentacją, prowadzonych na Wydziale Historycznym UAM. Praca dyplomowa została napisana pod kierunkiem prof. dr hab. Ireny Mamczak-Gadkowskiej (Poznań 2016). Nadmienię, że od 2005 r. jestem zatrudniona w opisywanej jednostce organizacyjnej UAM, tu zrobiłam doktorat w 2009 r., studia podyplomowe zaś są dla mnie dopełnieniem kwalifikacji $\mathrm{w}$ związku $\mathrm{z}$ archiwum pracownianym.

${ }^{2}$ Okres atlasowy rozumiem jako okres działalności archiwum w związku z powstawaniem Atlasu jezzyka i kultury ludowej Wielkopolski (t. I-VI, pod red. Z. Sobierajskiego i J. Burszty, Wrocław [i in.] 1979-1991; t. VII-XI, pod red. Z. Sobierajskiego, Wrocław-Poznań 1992-2005) i pozyskiwaniem nagrań gwarowych głównie do tego celu. Są to lata 1972-1986 - część zasadniczych nagrań, następnie do roku 1990 - pojedyncze, uzupełniające eksploracje.

${ }^{3}$ Zmiana terminologii wiąże się tak ze zmianą metodologii badawczej, jak i z przemianami, jakim uległa polska wieś na przestrzeni ostatnich dziesięcioleci.
} 
Niniejsze opracowanie ma na celu zebranie w jednej publikacji dotychczasowego stanu wiedzy na temat archiwum działającego obecnie przy Pracowni Dialektologicznej UAM (Instytut Filologii Polskiej, Wydział Filologii Polskiej i Klasycznej - budynek Collegium Maius przy ul. A. Fredry 10). Moim zamiarem jest zaprezentowanie historii i aktualnego statusu archiwum, scharakteryzowanie całego zasobu, jaki znajduje się w Pracowni Dialektologicznej UAM, a który wchodzi w skład archiwaliów dialektalnych (nie tylko fonografia), oraz przedstawienie zarówno sposobu funkcjonowania tego archiwum, jak też rozlicznych jego potrzeb.

Literatura dotycząca archiwum jest dość obfita (jak na tak małą komórkę, o stosunkowo niedługiej historii), choć w przeważającej większości dotyczy funkcjonowania archiwum do połowy lat 90. XX w.

Początków przedsięwzięcia należy upatrywać w okresie powojennym (w roku 1946), gdy na Uniwersytecie Poznańskim powstało Archiwum Fonograficzne Instytutu Zachodnio-Słowiańskiego (z inicjatywy doc. Ludwika Zabrockiego, przy poparciu prof. Mikołaja Rudnickiego i prof. Jana Otrębskiego).

Pierwsza publikacja „sprawozdawcza” dotycząca powstawania i funkcjonowania archiwum to artykuł Ludwika Zabrockiego Archiwum Fonograficzne Instytutu Zachodnio-słowiańskiego Uniwersytetu Poznańskiego (1948), w latach 1953-1990 ukazywały się - najpierw w „Biuletynie Fonograficznym”, następnie w "Slavia Occidentalis" - katalogi nagrań na płytach gramofonowych i taśmach magnetofonowych do roku 1969 (katalogi te zawierają także informacje o tematyce nagrań). W międzyczasie ukazały się artykuły: Niny Borowskiej Powstanie i rozwój Zakładu Fonograficznego U.P. (1953) oraz Zenona Sobierajskiego Z perspektywy ćwierćwiecza - akcja nagrywania dialektów w Poznaniu w latach 1946-1969 (1971). Kolejna ważna publikacja to artykuł Henryka Nowaka Od Archiwum Fonograficznego do Zakładu Dialektologii Polskiej Uniwersytetu im. Adama Mickiewicza w Poznaniu (2001), podsumowujący kolejny okres istnienia archiwum i jego macierzystej placówki badawczej. Natomiast najnowsze informacje o archiwum przynosi artykuł Jerzego Sierociuka Poznańskie archiwum dialektologiczne. Zasób nagrań fonograficznych, opracowanie (2015).

Łatwo zauważyć - choćby po tytułach - że wszystkie te publikacje skupiają się na zasobie fonograficznym (wszak najcenniejszym, unikatowym), pomijając kwestię towarzyszącej nagraniom dokumentacji czy spuścizny naukowej dialektologów związanych z poznańską placówką badawczą. 


\section{Historia}

Dzieje charakteryzowanego $\mathrm{w}$ niniejszej pracy archiwum zostały dotychczas wielokrotnie opisane. Można przyjąć, że na ten temat mamy wiedzę ugruntowaną i szczegółową. Za najważniejsze opisy dotyczące tej problematyki należy uznać: Ludwika Zabrockiego Archiwum Fonograficzne Instytutu Zachodnio-stowiańskiego Uniwersytetu Poznańskiego, Henryka Nowaka Od Archiwum Fonograficznego do Zakładu Dialektologii Polskiej Uniwersytetu im. Adama Mickiewicza w Poznaniu, Jerzego Sierociuka Poznańskie archiwum dialektologiczne. Zasób nagrań fonograficznych, opracowanie. Pierwszy z wymienionych artykułów z 1948 r. to prezentacja utworzonego w 1946 r. Archiwum Fonograficznego; drugi artykuł to dokładny opis przeobrażeń tego archiwum w kolejne placówki badawcze oraz podsumowanie pracy osób związanych $z$ tą instytucją, charakterystyka ilościowa zasobu fonograficznego do ok. 1990 r., a także przedstawienie potrzeb związanych z należytym funkcjonowaniem archiwum; trzeci artykuł - najnowszy - dotyczy przede wszystkim charakterystyki zasobu oraz sposobu jego katalogowania; autor zawarł w nim także ciekawe zestawienia dotyczące najstarszych nagrań i najstarszych rozmówców.

$Z$ racji tego, że temat jest zasadniczo wyczerpany, poniżej - zamiast tradycyjnego opisu - przywołam najważniejsze daty i zdarzenia dotyczące dziejów archiwum dialektologicznego.

Kalendarium archiwum Pracowni Dialektologicznej UAM

\begin{tabular}{|l|l|l|}
\hline \multicolumn{1}{|c|}{ Data } & \multicolumn{1}{|c|}{ Wydarzenie } & Założyciel/kierownik \\
\hline sierpień 1946 r. & $\begin{array}{l}\text { Początek prac organizacyjnych nad po- } \\
\text { wołaniem Archiwum Fonograficznego In- } \\
\text { stytutu Zachodniosłowiańskiego Uniwersy- } \\
\text { tetu Poznańskiego (potocznie "Archiwum } \\
\text { Fonograficzne") }\end{array}$ & doc. Ludwik Zabrocki \\
\hline 1 stycznia 1951 r. & $\begin{array}{l}\text { Przemianowanie Archiwum Fonograficz- } \\
\text { nego Instytutu Zachodniosłowiańskiego na } \\
\text { Instytut Fonograficzny Uniwersytetu Po- } \\
\text { znańskiego }\end{array}$ & dr Leon Kaczmarek \\
\hline 26 maja 1956 r. & $\begin{array}{l}\text { Przemianowanie Instytutu Fonograficznego } \\
\text { UP na Zakład Fonograficzny przy Katedrze } \\
\text { Jezzyka Polskiego UP doc. Zenon Sobierajski }\end{array}$ & dr Wiktor Jassem \\
\hline październik 1960 r. - & $\begin{array}{l}\text { Wyodrębnienie z Zakładu Fonograficznego } \\
\text { Pracowni Archiwizacji Gwar przy Katedrze } \\
\text { Jezzykoznawstwa Ogólnego UAM; działal- }\end{array}$ & doc. Zenon Sobierajski \\
ność tej Pracowni 1969 r. & \multicolumn{2}{|c|}{} \\
\hline
\end{tabular}




\begin{tabular}{|l|l|l|}
\hline \multicolumn{1}{|c|}{ Data } & \multicolumn{1}{|c|}{ Wydarzenie } & Założyciel/kierownik \\
\hline 1974 r. & $\begin{array}{l}\text { Powołanie Zakładu Dialektologii Polskiej } \\
\text { przy Instytucie Filologii Polskiej UAM (da- } \\
\text { lej: ZDP UAM) }\end{array}$ & $\begin{array}{l}\text { prof. Zenon Sobierajski } \\
\text { prof. Henryk Nowak } \\
\text { prof. Jerzy Sierociuk }\end{array}$ \\
\hline 1 kwietnia 2009 r. & $\begin{array}{l}\text { Przemianowanie Zakładu Dialektologii Pol- } \\
\text { skiej na Pracownię Dialektologiczną UAM } \\
\text { przy Instytucie Filologii Polskiej UAM. }\end{array}$ & prof. Jerzy Sierociuk \\
\hline
\end{tabular}

Opracowanie własne na podstawie: H. Nowak, dz. cyt., s. 201-212.

Wczytując się w poszczególne daty i towarzyszące im zmiany nazwy powołanej przez Zabrockiego placówki badawczo-archiwistycznej, spostrzeżemy, że nazwa "Archiwum” zanika w 1951 r. wraz z powołaniem do życia Instytutu Fonograficznego. W tym czasie o specyfice placówki świadczy utrzymujący się w oficjalnej nazwie człon drugi „Fonograficzny” (Instytut, Zakład). Następnie, w 1960 r., wraz z powstaniem Pracowni Archiwizacji Gwar, o pierwotnym charakterze placówki świadczy już tylko drugi człon nazwy „Archiwizacji”. Natomiast wraz z utworzeniem Zakładu Dialektologii Polskiej UAM w 1974 r., ślad po Archiwum (jako nazwie) zanika całkowicie aż po dziś dzień, choć dokumentacja fonograficzna gwar jest nadal priorytetem $\mathrm{w}$ funkcjonowaniu najpierw ZDP UAM, następnie PD UAM.

Omawiając dzieje placówki, należy jasno powiedzieć, że zasadniczo od lat 60. archiwum utożsamiane jest wyłącznie $\mathrm{z}$ fonoteką. Obecnie odzwierciedla ten fakt stan prawny - archiwum nie jest wyodrębnione jako samodzielna komórka, i choć spełnia wszystkie przesłanki, to w praktyce funkcjonuje jako twór pośredni między składnicą akt a formalnym archiwum. Ten fakt pociąga za sobą kolejne konsekwencje - w świetle obowiązujących przepisów pracownicy opiekujący się zbiorami mogą liczyć jedynie (i aż) na merytoryczne wsparcie Archiwum Uniwersytetu im. Adama Mickiewicza w Poznaniu4.

\section{Organizacja i zasób}

Pracownia Dialektologiczna UAM dysponuje bardzo interesującymi i wartościowymi zbiorami archiwalnymi, które zwykle są kojarzone $\mathrm{z}$ fonoteką. Tymczasem zasób to nie tylko nagrania tekstów gwarowych, ale również bogata do nich dokumentacja - tzw. protokoły (zwłaszcza z okresu Pracowni Archiwizacji Gwar i ZDP UAM) - w sumie dziewięć segregatorów i 53 różnej grubości teczki (widać obecność metalowych spinaczy), zapiski dialek-

\footnotetext{
${ }^{4} \mathrm{~W}$ tym miejscu pragnę podziękować uniwersyteckim archiwistom za życzliwość, cenne rady i wskazówki dotyczące zbiorów archiwalnych PD UAM.
} 
tologów związanych z Uniwersytetem (najcenniejsze są rękopiśmienne zapiski doc. Adama Tomaszewskiego - założyciela poznańskiej dialektologii, zm. 1945) oraz kartoteka z rozpisanymi przez dialektologów materiałami Tomaszewskiego, to także kwestionariusze do Atlasu jezzyka $i$ kultury ludowej Wielkopolski (dalej: AJKLW) ${ }^{5}$ oraz mapy próbne, brudnopisowe, niepublikowane; dalej: wypiski do słownika ludowego Wielkopolski (65 pudeł, nie wszystkie są pełne), fiszki prof. Sobierajskiego - Indeks wyrazów: gwary kujawskie (dwa pudła: A-K, K-P), prace magisterskie dotyczące gwar, aparatura techniczna będąca na wyposażeniu placówki (od początku jej powstania); w skład zasobów PD UAM wchodzą również obfite zbiory biblioteczne (darowizny, spuścizny, depozyty) oraz eksponaty etnograficzne (depozyty, darowizny). Dwie ostatnie wymienione pozycje, będące zasobem stricte pracownianym, warto tu omówić z uwagi na całokształt, jaki tworzą z archiwaliami. Wszystko to razem stanowi o specyficznym charakterze placówki, jaką jest PD UAM i jej archiwum.

Przyjrzyjmy się bliżej zawartości archiwum. Najpierw przedstawię zasób fonograficzny, jako najstaranniej uporządkowany i zadbany, następnie przejdę do omówienia archiwaliów papierowych i zbiorów bibliotecznych, by zakończyć na opisaniu przechowywanego sprzętu technicznego i eksponatów etnograficznych.

\section{Fonoteka}

Najważniejszym zbiorem archiwaliów w PD UAM jest fonoteka - najbardziej uporządkowana i zadbana, szczególnie po przeprowadzce w 2010 r., i to ją scharakteryzuję w pierwszej kolejności.

W skład zasobu fonograficznego wchodzą oryginały i tzw. kopie, czyli zdigitalizowane (na płytach $\mathrm{CD}$ ) nagrania mowy ludowej z płyt i taśm.

Należy wspomnieć, że nagrania zdigitalizowane znajdują się w pracowni na czwartym piętrze, $\mathrm{w}$ szafach przeciwogniowych w dwóch pomieszczeniach (brakuje kopii zapasowych!), oryginały nagrań oraz „papierowa” część zasobu znajdują się w pomieszczeniu magazynowym przynależnym do pracowni, a zlokalizowanym w piwnicy (!) Collegium Maius.

Mówiąc o fonotece, mam na myśli dwuczęściowy podział zasobu, liczącego obecnie 2664 jednostki archiwalne ${ }^{6}$. Można tu mówić o dwóch głównych zespołach archiwalnych - wprawdzie oficjalnie nigdy niewyodrębnionych, ale w świadomości pracowników PD UAM funkcjonujących - mianowicie:

${ }^{5}$ Z. Sobierajski, Kwestionariusz do Atlasu jezzyka i kultury ludowej Wielkopolski, cz. I-III, Poznań 1972.

${ }^{6}$ Myślę tu o płytach CD, które zawierają zarówno dawne (zdigitalizowane) nagrania, jak i te współczesne. Liczba oryginałów przechowywanych $w$ archiwum jest niższa $z$ tego względu, że część, np. studenckich nagrań na kasetach magnetofonowych, była oddawana studentom (nośnik był prywatną własnością studenta). 
zespole archiwalnym nagrań do 1990 r. (a w nim nagrania tzw. atlasowe i pozostałe) oraz o zespole archiwalnym nagrań po $1990 \mathrm{r}$.

Pierwszy zespół archiwalny cechuje inna niż dziś metodologia i technika nagrań. Dialektolodzy nastawieni byli głównie na archiwizowanie rozmów z najstarszymi mieszkańcami wsi, a następnie według kwestionariusza do AJKLW. Możliwości techniczne pozwalały na krótkie nagrania, najpierw $\mathrm{w}$ studiu nagraniowym, potem $\mathrm{w}$ terenie - zwykle $\mathrm{w}$ specjalnie do tego celu wyposażonym samochodzie $\mathrm{z}$ agregatem prądotwórczym do sprzętu nagrywającego. W pierwszych latach funkcjonowania Archiwum Fonograficzne dysponowało następującymi sprzętami: „aparaturami do nacinania typu »Telefunken« $\mathrm{i}$ »Siemens«. Niektóre części aparatur są pochodzenia krajowego (jeden zespół wzmacniaczy typu »Ramar « - Poznań oraz dwa mikrofony produkcji firmy »Liersch « - Poznań). W bieżącym jeszcze roku otrzyma Archiwum zespół nacinający firmy angielskiej M.S.S. Recording Company Limited Manufactures of Sound Recording Equipment. Colnbrook, England. Poza tym dysponuje Archiwum filmowym aparatem dźwiękowym typu "Siemens « (projektor)" ${ }^{7}$. Jak podaje Henryk Nowak, dzięki funduszom ministerialnym, Archiwum zostało wyposażone $\mathrm{w}$ dwa studia nagraniowe oraz sprzęt do nagrywania, nie tylko stacjonarnego, ale i w terenie, zatem wspomniany przez Zabrockiego nacinacz „»MMSS Recording Co Ltd « oraz dwa komplety przenośnej aparatury typu »Birmingham Sound Reproducers «i »Simon Sound Service« [...]. Zakupiono też dwa magnetofony (typu »Twin-Trax mod. 910« i »Rylec AR 2«), mikrofony, specjalny adapter służący do transkrypcji tekstów utrwalonych na płytach oraz niezbędny sprzęt pomocniczy, a także parę tysięcy lakierowanych płyt do nagrywania tekstów gwarowych. Obsługą i konserwacją tychże urządzeń zajmowało się dwóch pracowników technicznych" ${ }^{8}$. Jako ciekawostkę dodam, że placówka dialektologiczna dysponowała swego czasu samochodami: półciężarówką typu BMW w pierwszych latach funkcjonowania Archiwum Fonograficznego oraz od połowy 1958 r. do ok. 1969 r. furgonetką „Nysa” (odpowiednio przerobioną na mobilne studio nagraniowe).

Zasób fonograficzny z tego okresu podsumował prof. Nowak: „Stan jednostek archiwalnych fonoteki gwarowej jest następujący: teksty nagrano na (naciętych dwustronnie) 122 płytach gramofonowych decelitowych (przeciętny czas nagrania to 6 minut) i 794 płytach lakierowanych (9 minut nagrania) oraz na 750 szpulach taśmy magnetofonowej (zwykle 30 minut nagrania). Te foniczne archiwalia dialektologiczne, wyrażone w jednostkach czasu, dają łącznie około 520 godzin nagranej mowy ludowej [z 520 miejscowości J.K.]. Przeszło połowa zgromadzonych tekstów gwarowych jest wynikiem

\footnotetext{
${ }^{7}$ L. Zabrocki, dz. cyt., s. 515.

${ }^{8}$ H. Nowak, dz. cyt., s. 202.
} 
pracy terenowej prof. Z. Sobierajskiego, który nagrał je aż w 280 miejscowościach - na 537 płytach gramofonowych i na 365 rolkach taśmy magnetofonowej. Kolejne miejsca w tej akcji zajmują: H. Nowak, który nagrał teksty w 95 miejscowościach, H. Skoczylas-Stawska - w 80 wsiach na obszarze dawnej ziemi wieluńskiej i terenach przyległych, L. Zabrocki - w 47 miejscowościach, J. Chodera - w 9 wsiach i M. Hasiuk w 7 wsiach (gwary litewskie koło Sejn $)^{\prime \prime}$. Informacje dotyczące tematyki nagrań do 1969 r. zawarte są w katalogach taśmoteki i płytoteki, publikowanych w „Biuletynie Fonograficznym” i "Slavia Occidentalis" (zob. Bibliografia). Najstarsze zarchiwizowane nagranie pochodzi z 8 sierpnia 1945 r., najstarszy zaś nagrany informator urodził się w 1885 r. ${ }^{10}$ Nagrania pochodzą zarówno z Wielkopolski, jak też innych regionów kraju; nagrano wówczas również gwary polskie z zagranicy i gwary innych języków słowiańskich. W sumie, po zdigitalizowaniu zespół ten liczy 716 j.a., co stanowi ok. 27 proc. całości zasobu fonograficznego dzisiejszego archiwum. W tym miejscu zaznaczę, że ilość materiałów zdigitalizowanych nie odpowiada relacji 1:1. Ponieważ pierwsze nagrania były bardzo krótkie, natomiast akcja digitalizacji odbywała się w ramach zwykłego funkcjonowania ówczesnego ZDP UAM (zatem bez dodatkowego wsparcia finansowego), umieszczano nagrania z kilku płyt (z tej samej miejscowości i z tym samym informatorem) na jednym krążku CD opatrzonym odpowiednią informacją. Stąd ilość jednostek archiwalnych omawianego zespołu jest różna przed i po digitalizacji. Zarządzenie nr 27 Naczelnego Dyrektora Archiwów Państwowych z 10 sierpnia 1972 r. wyraźnie wykazywało, że podstawową jednostką archiwizacyjną materiałów dźwiękowych jest nagranie, które może składać się z części lub kilku jednostek fizycznych; nagranie rozumiemy jako wynik działalności jednego twórcy - tu jednego informatora. W związku z tym, że nośniki mieściły po sześć minut rozmowy, podczas digitalizacji scalano poszczególne części (płyty) w jedną, odpowiednio opisaną. W tym miejscu wspomnę, że nagrania $\mathrm{z}$ tego zespołu mają sporządzony katalog kartkowy.

Drugi zespół archiwalny nagrań po 1990 r. (do dziś) to potężny zasób eksploracji rejestrowanych nowoczesnym sprzętem, przy zupełnie zmienionej metodologii. Przede wszystkim nagrania utrwalono przy pomocy dyktafonów - najpierw kasetowych firmy SONY (typ TCM) lub Panasonic, następnie na prywatnych (pracowników) dyktafonach cyfrowych, m.in. firmy SONY, Olympus. Metodologicznie współczesne badania terenowe są skoncentrowane wokół pozyskiwania materiałów do słownika gwar wielkopolskich.

\footnotetext{
9 Tamże, s. 205.

${ }^{10}$ Por. Sierociuk J., Poznańskie archiwum dialektologiczne. Zasób nagrań fonograficznych, opracowanie, [w:] Dziedzictwo audiowizualne w warsztacie badawczym historyka i procesie dydaktycznym, pod red. R. Reczka, Poznań 2015.
} 
Rozmowy z informatorami są sterowane kwestionariuszem tematycznym, czyli każde nagranie ma swój temat przewodni, a dobór informatorów podyktowany jest przynależnością do odpowiedniego przedziału pokoleniowego $^{11}$. W związku z zaniechaniem finansowania badań terenowych, pracownicy wykonują je na własnym sprzęcie, za własne pieniądze. $Z$ tego też względu wszystkie jednostki archiwalne sporządzone przez osoby zatrudnione w ZDP UAM i PD UAM (po 1996 r.) są traktowane jako depozyt - łącznie są to 744 nagrania, co odpowiada ok. 28 proc. całego zasobu fonograficznego. W skład zespołu archiwalnego wchodzą także nagrania wykonane przez studentów, doktorantów i osoby współpracujące z PD UAM (ówczesnym ZDP UAM), np. regionalistów, uczniów szkół gminnych i powiatowych w ramach projektów edukacyjnych itd. - w sumie są to 1204 nagrania, co stanowi ok. 45 proc. całego zasobu fonograficznego.

W skład omawianego zespołu nagrań wchodzi w sumie 1948 fonograficznych j.a. (płyt CD), co stanowi 73 proc. całego zasobu fonoteki i daje ponad dwa tys. godzin nagrań (do 9 kwietnia 2016 r.). W tym: depozyty pracowników: a) obecnych: prof. Jerzy Sierociuk - 479 j.a., dr Justyna Kobus (także jako: Perkowska) - 121 j.a., dr Błażej Osowski - 78 j.a.; b) byłych: mgr Alicja Sobańska - 42 j.a., mgr Anna Kunstowicz - 14 j.a., mgr Anna Gliszczyńska 10 j.a.

W tym miejscu nadmienię, że dla dialektologa najważniejszą miarą zasobu fonograficznego jest jednostka czasu, mniejsze znaczenie ma jednostka archiwalna. Przykładem popierającym ten punkt widzenia niech będą płyty czy taśmy z pierwszego scharakteryzowanego zespołu archiwalnego, gdzie najdłuższe nagranie liczyło trzydzieści minut. W zespole archiwalnym nagrań po $1990 \mathrm{r}$. trzydziestominutowe nagranie to minimum usprawiedliwione szczególnymi warunkami (np. nietrafiony informator, nagrania robione przez dzieci, młodzież $\mathrm{w}$ ramach projektów edukacyjnych). Założenie jednak jest takie, że minimalne nagranie winno liczyć dziewięćdziesiąt minut. Od kilkunastu lat założenie to jest konsekwentnie realizowane, co nie znaczy, że nie napływają nagrania krótsze, np. ok. 45 minut, obok ponad trzygodzinnych. Wszystko to jest uzależnione w znacznej mierze od czynnika ludzkiego (kto, kogo, w jakich warunkach nagrywa). Obecnie bowiem nie jest łatwo pozyskać informatora do badań dialektologicznych. Ludzie, przynajmniej w Wielkopolsce, są zamknięci i nieufni, trudno ich przekonać, co do celu i potrzeby takich rozmów. Jeśli chodzi o możliwości sprzętowe, to są one nieporównywalnie lepsze od tych sprzed chociażby dziesięciu lat. Nagrywanie cyfrowe sprawia, że nie trzeba wprowadzać przerw technicznych związanych z odwróceniem taśmy czy zmianą baterii (poziom baterii jest wyświetlany na

11 J. Sierociuk, Założenia metodologiczne badań języka wsi, [w:] Poznańskie Spotkania Jezykoznawcze, t. IX, red. Z. Zagórski, i Z. Krążyńska, Poznań 2003, s. 134. 
dyktafonie i można przed nagraniem włożyć nowe baterie, jeśli poziom energii może okazać się niewystarczający). Niewielkie rozmiary sprzętu i bezgłośność działania minimalizują wzrost poziomu stresu u osób badanych, a poza tym nieznacznie tylko (pod względem fizycznym) obciążają eksploratora.

\section{Dokumentacja papierowa}

Dokumentacja papierowa to przede wszystkim protokoły do nagrań - dotyczą one pierwszego zespołu fonograficznego. Protokoły zostały wykonane na słabej jakości papierze (tzw. kwaśnym papierze), co sprawiło, że przez lata ich stan wyraźnie się pogorszył (zalecane jest odkwaszenie tych dokumentów). Z punktu widzenia merytorycznego protokoły są o tyle interesujące, że dostarczają obok danych technicznych o nagraniu wielu - dziś niemożliwych do uzyskania - informacji na temat informatora, często wraz ze zdjęciem osoby badanej. Dziś są zatem źródłem nie tylko informacji językowych czy psychologicznych, ale i etnograficznych (co raczej nie było założeniem protokolantów).

Następnie: zapiski dialektologów - tu można wyodrębnić (choć w praktyce nie zostało to zrobione) zespoły archiwalne zamknięte, związane z twórcą zasobu, czyli 1. Adam Tomaszewski (zapiski rękopiśmienne i kartoteka licząca ponad 46300 fiszek), 2. Zenon Sobierajski (wypiski do słownika ludowego Wielkopolski, indeks alfabetyczny do słownika gwar kujawskich), 3. Henryk Nowak (rękopisy; dokumentacja osobista i służbowa), a także zespół dokumentacji dla AJKLW (kwestionariusze, mapy próbne, brudnopisowe i niepublikowane; dokumenty formalne, np. umowy, podania, wnioski itd.).

Dokumentacja papierowa nie została dotychczas zinwentaryzowana.

\section{Dawna aparatura techniczna}

W skład archiwum wchodzi również dawna aparatura techniczna, będąca na wyposażeniu placówki od początku jej powstania. Nie udało się zachować wszystkich sprzętów, zwłaszcza wyposażenia z mobilnego studia nagraniowego.

Część starej aparatury posłużyła do odtworzenia oryginałów w celu ich digitalizacji.

Aktualnie w PD UAM znajdują się następujące sprzęty minionej epoki ${ }^{12}$ :

- magnetofon szpulowy Unitra Aria MDS 2412 do odsłuchu i nagrywania tekstów gwarowych;

- adapter Unitra Fonica GS „Bernard” 434 do odsłuchu nagrań gwarowych;

12 Wiele zdjęć omawianych sprzętów wykonał w PD UAM i dołączył do artykułu J. Sierociuka (Poznańskie archiwum dialektologiczne...) dr Rafał Reczek, redaktor tomu Dziedzictwo audiowizualne w warsztacie badawczym historyka i procesie dydaktycznym, Poznań 2015, s. 148-152. 
- adapter Telefunken do odsłuchu nagrań gwarowych;

- zestawy magnetofonów i equalizerów do nagrań z winylu na współczesne nośniki;

- nacinacz do płyt M.S.S Recording Co. Ltd.

Sprzęty z lat. 70. i 80.:

- magnetofon „Fonia” MS 171 do taśm o większej średnicy;

- magnetofon M 3401 S;

- gramofon WG 580;

- gramofon Fonomaster G601A;

- gramofon stereofoniczny GS-434;

- gramofon WG-902;

- magnetofon M2412 NF 31500 ST86;

- magnetofon Aria SD MDS 2411;

- magnetofon Altus D-600;

- magnetofon kasetowy x2;

- magnetofon MK 250.

Sprzęty te $\mathrm{w}$ większości są sprawne. Jedynie nacinacz i magnetofon „Fonia" nie zostały dotychczas uruchomione, co jest jednak zamiarem pracowników obliczonym na niedaleką przyszłość, w celach poznawczych oraz promocyjnych archiwum i całej PD UAM.

Sprzęty zostały zinwentaryzowane przez Dział Inwentaryzacji UAM.

\section{Zbiory biblioteczne}

Do tej części zasobu archiwalno-pracownianego należą prace magisterskie i doktorskie dotyczące gwar, a powstałe w ZDP UAM i PD UAM (charakter stricte archiwalny). W sumie jest ich ok. 270. Trudno ustalić ich ostateczną liczbę, ponieważ nie zostały dotąd zinwentaryzowane i wśród stojących na regałach pozycji mogą być dublety.

Z kolei do zasobu typowo pracownianego należą pokaźne zbiory biblioteczne, w skład których wchodzą nie tylko zakupy poczynione przez Uczelnię dla potrzeb pracowników (niezbędna literatura przedmiotu) - ok. dziesięć proc. całego zasobu bibliotecznego, ale również spuścizna po prof. Henryku Nowaku - ok. dziesięć proc., darowizna prof. Anny Kowalskiej - ok. dziesięć proc., depozyty: prof. Tadeusza Lewaszkiewicza (ok. dziesięć proc.) i kierownika PD UAM prof. Jerzego Sierociuka (ok. sześćdziesiąt proc. i stale wzrasta).

Zbiory biblioteczne nie zostały jak dotąd skatalogowane. A od czasu przeprowadzki w 2010 r. z al. Niepodległości (Collegium Novum) do Collegium Maius przy ul. Fredy 10, znajdują się w znacznym nieładzie, jedynie orientacyjnie poukładane na regałach w sposób (docelowo) tematyczny. Pracownicy noszą się z zamiarem stworzenia katalogu komputerowego całego księgo- 
zbioru, co wydaje się zadaniem niewykonalnym dla tak małego zespołu pracowniczego.

\section{Eksponaty etnograficzne}

Eksponaty etnograficzne znajdujące się obecnie w PD UAM można zaliczyć w skład depozytów tejże placówki, przekazanych w zdecydowanej większości przez prof. Jerzego Sierociuka (98 proc.); w pozostałej liczbie przedmioty zostały podarowane pracowni przez studentów lub sympatyków.

Z ciekawszych eksponatów etnograficznych warto wymienić: cep, kołowrotki, kierzynkę, kosę, kreepulec, opołki ('koszyk do wyrastania chleba'), czop do beczki drewnianej, koło drewniane w żelaznej obręczy, podkowy, drewniane strugi stolarskie, chomąto, żelazko na węgiel i na duszę, rzeźby ludowe $i$ in.

Eksponaty nie są zinwentaryzowane.

\section{Ochrona i konserwacja}

Państwowy nadzór nad archiwalnymi materiałami audiowizualnymi obejmuje Narodowe Archiwum Cyfrowe, które powstało na mocy Rozporządzenia Ministra Kultury i Dziedzictwa Narodowego z dnia 6 lutego 2008 r. w sprawie zmiany nazwy i zakresu działania Archiwum Dokumentacji Mechanicznej w Warszawie. W działalności NAC oraz w Zarządzeniach Naczelnego Dyrektora Archiwów Państwowych należy szukać standardów w postępowaniu z dokumentacją dźwiękową.

Materiały audiowizualne - jak każdy inny dokument - podlegają ocenie i selekcji. Zasadniczo dzieli się je ze względów merytorycznych i technicznych: „merytoryczne - służące ocenie wartości treści i formy dokumentu pod względem historycznym (znaczenie dokumentu dla historii, polityki, gospodarki oraz kultury), oraz techniczne - obejmujące jakość obrazu i dźwięku, stan zachowania nośnika informacji, to znaczy papieru fotograficznego, taśmy magnetofonowej, płyty gramofonowej [...]. Kryteria merytoryczne powinny być nadrzędne w stosunku do technicznych, a materiałów uznanych z uwagi na formę treść za ważne i unikatowe nie należy brakować, nawet w przypadku ich złego stanu technicznego"13. Krzysztof Pątek zwraca również uwagę na osiem innych, obok podstawowych, cech wartościujących nagranie czy film, do których należą m.in.: utrwalona reakcja audytorium, czynniki emocjonalne towarzyszące przemówieniom, elementy dźwięku i obrazu

${ }^{13}$ K. Pątek, Dokumentacja audiowizualna $i$ mikrofilmowanie w archiwach państwowych, [w:] Technika archiwalna w XX wieku, pod red. S. Sierpowskiego i J. Wiśniewskiego, Poznań 2001, s. 33 . 
charakteryzujące przynależność środowiskową, tzw. gest foniczny (typowe dla osoby cechy związane z tokiem i sposobem wypowiedzi), elementy dźwięku i obrazu stanowiące narzędzie badań w dziedzinie nauk pomocniczych historii - w językoznawstwie, etnografii itp., ubiory i tendencje ówczesnej mody ${ }^{14}$.

Wszystkie te kryteria były i są uwzględniane w czynieniu pieczy nad zbiorem fonograficznym archiwum PD UAM.

W celach ochrony zasobu archiwalnego kierownik ówczesnego ZDP UAM, a dzisiejszej PD UAM, prof. Sierociuk w 2003 r. zarządził akcję digitalizacji fonoteki. Za techniczną część procesu odpowiadał zatrudniony wówczas w ZDP UAM technik mgr inż. Bronisław Obrowski. Prace rozpoczęto od nagrań najstarszych - nośniki były już mocno nadszarpnięte zębem czasu (i zapewne niekorzystnymi warunkami przechowywania). Dzięki zaangażowaniu mgr. Obrowskiego udało się ocalić większość nagranych tekstów (szacunkowo 98 proc.).

Akcja digitalizacji wiązała się z dotychczas niewykonywaną czynnością odkurzenia nośników - szczególne kłopoty związane były z taśmami. Zły stan nośników sprawił, że często dochodziło do rozciągania, kruszenia, zrywania się taśm na szpulach, co skutkowało utratą części nagrania. W trakcie prac okazało się, że największym problemem była zła jakość nagrania (trzeba było przepuszczać dźwięk przez kilka nośników i programów komputerowych). Przyczyną tego stanu rzeczy zapewne był brak odpowiednich warunków przechowywania, które nadal nie jest łatwo uzyskać (o czym szerzej w dalszej części artykułu).

Akcja digitalizacji zespołu fonograficznego do 1990 r. zakończyła się w 2013 r. W tym czasie regularnie napływały nagrania bieżące. Wszystkie zostały skatalogowane w stworzonym do tego celu katalogu komputerowym (w programie MS Excel). Strukturę katalogu opisał Jerzy Sierociuk w artykule Poznańskie archiwum dialektologiczne. Zasób nagrań fonograficznych, opracowa$n i e^{15}$. Niżej, dla celów informacyjnych, również przywołam fragment tego katalogu (zaznaczam, że jest on cały czas w wersji roboczej; ryc. 1.).

Struktura katalogu jest następująca:

- Ile? - kolumna zawiera informację o liczbie płyt z danej miejscowości; liczby oznaczają kolejną płytę z danego punktu badawczego; brak liczby oznacza, że dotychczas w danej miejscowości wykonano tylko odnotowane nagranie;

- Miejscowość - oznacza miejsce nagrania;

- Gmina - Powiat - oznacza gminę lub powiat, w jakich znajduje się miejscowość, z której pochodzi nagranie;

\footnotetext{
14 Zob. tamże, s. 33-34.

15 J. Sierociuk, Poznańskie archiwum dialektologiczne, s. 138-145.
} 
-Województwo - oznacza województwo, w obrębie którego mieści się miejscowość, z której pochodzi nagranie; tu również wpisuje się nazwę państwa, jeśli nagranie zostało wykonane za granicą;

- Nr. kol. - tu umieszcza się numer pozycji katalogowej (można go przyrównać do numeru w rejestrze), nadawany w kolejności, w jakiej nagranie (j.a.) było wprowadzane do katalogu;

- Nazwisko informatora - tu wpisuje się imię i nazwisko osoby, która jest nagrana; w przypadku, gdy w nagraniu brało udział więcej osób, to w katalogu widnieją dane tylko pierwszego informatora;

- R. ur. - oznacza rok urodzenia informatora;

- Kto nagrał - kolumna zawiera imię i nazwisko eksploratora; w przypadku, gdy nagranie wykonało więcej osób, to w katalogu widnieją dane tylko pierwszego eksploratora;

- Data nagr. - oznacza datę składającą się z roku-miesiąca-dnia, w którym zostało wykonane nagranie;

- Transkrypcja - kolumna zawiera informację o tym, czy nagranie zostało przetranskrybowane oraz kto zrobił tę transkrypcję;

- Pas - oznaczenie kartograficzne; pasy orientują położenie według równoleżników, liczy się je z północy na południe;

- Słup - oznaczenie kartograficzne; pasy orientują położenie według południków, liczy się je z zachodu na wschód;

- Czas - oznacza długość nagrania wyrażoną w jednostkach czasu, tj. minutach (") i sekundach (");

- Taśma/płyta - informuje o postaci nośnika oryginalnego - płyta czy taśma (dotyczy zespołu archiwalnego nagrań do 1990 r.);

- Data kopii - oznacza datę składającą się z roku-miesiąca-dnia, w którym nagranie z nośnika oryginalnego zostało przegrane na płytę CD i po skatalogowaniu włączone do fonoteki;

- Uwagi - kolumna zawierająca rozmaite informacje, np. rozwiązania skrótów, temat nagrania, liczba wykonanych kopii, rodzaj nagrania (np. powtórzone, uzupełnienie, $\mathrm{w}$ dwóch częściach itp.), nieścisłości metryczki z nagranymi danymi itd.;

- Segment - oznacza lokalizację CD w szafie przeciwogniowej;

- Suma - długość nagrania wyrażona w jednostkach czasu, w zapisie: godzina:minuta:sekunda.

Czynność katalogowania nagrań współczesnych wiąże się ściśle z nośnikami, na których się pracuje $\mathrm{w}$ terenie. Dotychczas, tj. do czasu, gdy zatrudniony był technik, a nagrań dokonywano sprzętem analogowym, kasety wraz z metryczką (nagraną i papierową) były przekazywane do przegrania na CD oraz skatalogowania i włączenia do fonoteki. Dziś brakuje technika, który by się tym zajmował, a nagrania dostarczane w postaci cyfrowej gromadzone są w prywatnych folderach bez natychmiastowego ich katalogowania. 


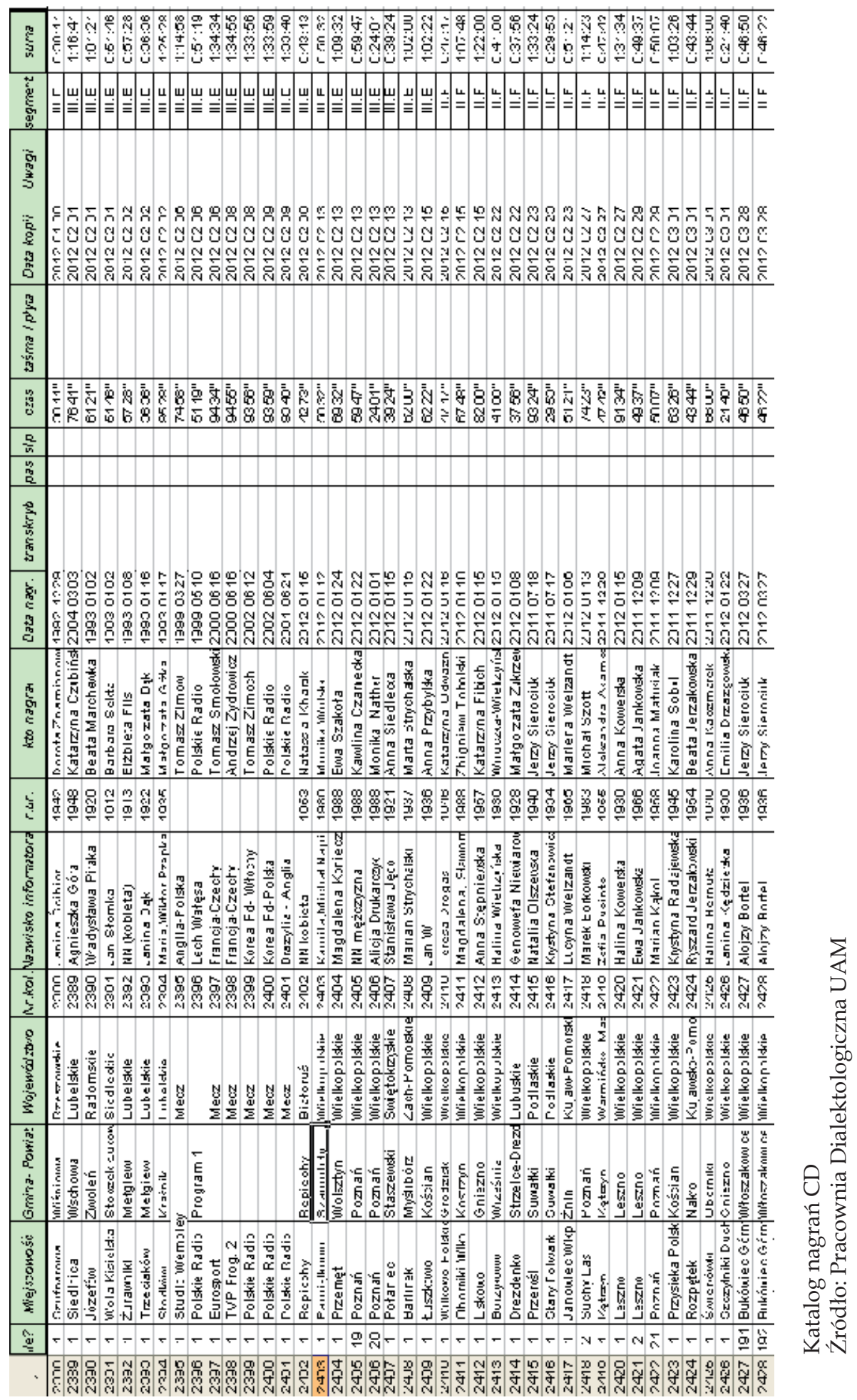


Dla potrzeb niniejszego opracowania skatalogowałam nagrania od 2013 r. do marca 2016 r. Jednakże to nie wystarczy - konieczne są działania metodyczne, regularne, codzienne. Niezbędne jest opracowanie instrukcji określającej sposób przekazywania nagrań do katalogowania i umieszczania w fonotece, a przede wszystkim wyznaczenia osoby za ten proces odpowiedzialnej (to jednak problem kadrowy, którego nie jesteśmy w stanie - jako Pracownia samodzielnie pokonać).

\section{Aktualne problemy i potrzeby}

Pracownia Dialektologiczna UAM liczy czterech pracowników, z czego troje jest dialektologami. Osoby te prowadzą prace badawcze i dydaktykę ( $\mathrm{z}$ wyjątkiem pracownika naukowo-technicznego). Od 2013 r. zespół został pozbawiony technika, odpowiadającego za digitalizację najstarszych nagrań, prowadzenie katalogu i szereg spraw związanych ze sprawnym funkcjonowaniem pracowni (zwłaszcza po przeprowadzce do nowej siedziby). W związku z tym zahamowany został proces porządkowania zasobów i bieżącej aktualizacji katalogu nagrań. Zatem pierwszą palącą potrzebą jest uzupełnienie niedoboru kadrowego jednostki.

Równie dojmujący, w pracy bieżącej, jest brak odpowiedniego zaplecza technicznego. Pracownia wyposażona jest $\mathrm{w}$ większości w sprzęt przestarzały. Choć należy zauważyć, że w 2017 r. został zakupiony komputer stacjonarny dobrej jakości, nowy (wcześniej otrzymywano jedynie komputery przechodzone). Dotychczasowy sprzęt był niewystarczający z uwagi na charakter wykonywanej na nim pracy (nie jest to tylko pisanie w Wordzie, ale tworzenie potężnych baz danych, które obecnie zapisywane są na sprzęcie prywatnym kierownika pracowni). Niezbędne dyski zewnętrzne do przechowywania nagrań już zdigitalizowanych (jak wiadomo, płyty CD powinny być po pięciu latach przegrane na nowe nośniki) zostały dostarczone Pracowni również $\mathrm{w}$ przeciągu mijającego roku; dyski pozwalają na $\mathrm{w}$ miarę bezpieczne przechowywanie archiwaliów, baz danych itd. w jednym miejscu. Zarazem więcej niż jeden taki nośnik zapewnia wykonanie kopii zabezpieczających. Dodam, że do przechowywania archiwaliów dźwiękowych zostało udostępnione miejsce na serwerze uniwersyteckim.

Bardzo przydatny w pracowni technicznej byłby skaner umożliwiający digitalizację dokumentacji archiwalnej (m.in. protokołów z nagrań, rękopisów, map próbnych itd.). Ten, który wpisany został na stan, jest już mocno przestarzały.

W kwestii sprzętu warto nadmienić, że archiwum winno być na bieżąco uzupełniane aktualnie wykonywanymi nagraniami. Dziś - co już było wspo- 
mniane - zasób fonograficzny składa się w sporej części z depozytów pracowniczych. Należałoby zatem zadbać o dyktafony cyfrowe (wraz z dobrymi jakościowo bateriami) dla pracowników, rozliczanie wyjazdów terenowych na zasadach delegacji wraz z uwzględnieniem realiów związanych $\mathrm{z}$ transportem (obecnie pracownik może otrzymać zwrot kosztów podróży wyłącznie środkami transportu publicznego, podczas gdy do większości wsi dojazd taki jest utrudniony; zdroworozsądkowe myślenie nakazuje więc korzystać $\mathrm{z}$ transportu prywatnego, by zaoszczędzić czas i być w terenie odpowiednio długo, nie ograniczając się rozkładami jazdy PKS; praktyka uczy, że wyprawa terenowa może skończyć się po pół godzinie, a można też spędzić w danej wsi cały dzień, by wrócić późnym wieczorem, czasem nawet nocą).

Sama digitalizacja nie stanowi rozwiązania problemu. W celu zachowania dobrostanu oryginałów niezbędna jest konserwacja, np. dokumentów wykonanych na tzw. kwaśnym papierze, czy przegrywanie płyt CD oraz stworzenie warunków sprzyjających przechowywanemu zasobowi, zgodnie z jego potrzebami., tj. inną temperaturę i wilgotność należy zapewnić taśmom (temperatura $15-18^{\circ} \mathrm{C}$, wilgotność $30-40$ proc. $\mathrm{RH}^{16}$ ), inne warunki potrzebne są płytom gramofonowym (temperatura $18-20^{\circ} \mathrm{C}$, wilgotność $40-45$ proc. $\mathrm{RH}^{17}$ ) i optycznym (temperatura poniżej $20^{\circ} \mathrm{C}$, wilgotność $20-50$ proc. $\mathrm{RH}^{18}$ ), a jeszcze inne dokumentacji papierowej (temperatura poniżej $10^{\circ} \mathrm{C}$, wilgotność 30-40 proc. $\mathrm{RH}^{19}$ ). W 2016 r. Pracownia otrzymała od Instytutu Filologii Polskiej środki na zakup bezkwasowych opakowań do przechowywania dokumentacji papierowej.

Co się tyczy wyposażenia, pomieszczenie magazynowe (archiwum właściwe) ma wprawdzie nowe regały, ale z płyty MDF, podczas gdy najbardziej wskazane byłyby metalowe dla dokumentacji papierowej i drewniane lub z tworzyw sztucznych dla taśm i pły ${ }^{20}$. Przydałyby się również specjalne szuflady na mapy w miejsce obecnego stojaka, który kumuluje zwinięte w rulony egzemplarze. Przemysław Wojciechowski informuje, że „Mapy i plany przechowuje się $w$ rulonach umieszczonych $w$ tubusach (najlepiej z tworzywa sztucznego) albo - co jest najkorzystniejsze - w drewnianych szufladach

${ }^{16}$ Naczelna Dyrekcja Archiwów Państwowych, Zasady postępowania z materiałami archiwalnymi. Ochrona zasobu archiwalnego, www.archiwa.gov.pl/images/docs/Zasady_Postepowania_ NL_2011_1.pdf (dostęp 25 kwietnia 2016). Przemysław Wojciechowski podaje dla taśm magnetofonowych następujące wartości: temperatura $15-18^{\circ} \mathrm{C}$, wilgotność $50-60$ proc. $\mathrm{RH}$ (P. Wojciechowski, Przechowywanie i konserwacja akt, [w:] Metodyka pracy archiwalnej, pod red. S. Nawrockiego i S. Sierpowskiego, Poznań 2004, s. 252), podczas gdy K. Pątek podaje inne wartości dla taśm: temperatura $18-20^{\circ} \mathrm{C}$, wilgotność $40-50$ proc. (K. Pątek, dz. cyt. s. 35).

17 Naczelna Dyrekcja Archiwów Państwowych, dz. cyt.

18 Tamże.

19 Tamże. Wojciechowski podaje wartości dla przechowywania papieru: temperatura 14-18 ${ }^{\circ} \mathrm{C}$, wilgotność 50-60 proc. RH (P. Wojciechowski, dz. cyt., s. 248).

${ }^{20}$ K. Pątek, dz. cyt., s. 35. 
dużych szaf w postaci rozłożonej [...] Należy unikać przechowywania dokumentacji kartograficznej i technicznej w szafach metalowych, gdyż panuje tam zawsze duża wilgotność. $Z$ tych względów w ścianach tylnych i bocznych muszą znajdować się otwory zapewniające obieg powietrza, ale jednocześnie chroniące przed przenikaniem do środka kurzu"21.

Jednakże najbardziej dojmujący jest brak oficjalnej nazwy i określenia statusu prawnego archiwum. Najlepszą byłaby taka, która byłaby stała, pomimo zmian nazwy jednostki organizacyjnej (a było ich wiele na przestrzeni siedemdziesięciu lat istnienia).

\section{Działalność}

Obecnie PD UAM nastawiona jest na powiększanie zasobu fonoteki o nowe nagrania. Cel jest jasny: archiwizacja i monitorowanie zmian językowych ludności zamieszkującej tereny wiejskie oraz zebranie i opracowanie materiałów do słownika gwarowego Wielkopolski.

Zasób fonograficzny, choć skatalogowany, nie jest w wystarczającym stopniu znany i udostępniany. Przez wiele lat udostępnianie wiązało się z rozpowszechnianiem tekstów gwarowych w formie opracowanej22. Udostępnianie było ściśle związane z dydaktyką i pracą badawczą. Nagrane teksty były transkrybowane i wydawane w postaci zbiorów tekstów gwarowych, głównie autorstwa Zenona Sobierajskiego, np. Polskie teksty gwarowe z ilustracja dźwiękowa (1959-1964) lub w postaci pomocy dydaktycznych, np. Dialekty polskie i folklor z różnych regionów (1991). Następnie nagrania trafiały do tzw. lamusa. Nikt nie mógł z nich skorzystać.

Od czasu, gdy kierownictwo placówką przejął prof. Sierociuk, zasób archiwalny jest udostępniany. Dotyczy to przede wszystkim materiałów z zespołu nagrań do 1990 r., czyli opracowanych (ale i najcenniejszych, mających wartość historyczną). Nagrania (nie opracowania nagrań) udostępniane są m.in. badaczom, studentom piszącym prace magisterskie, maturzystom opracowującym tematy związane z gwarami, a nawet członkom rodzin informatorów nagranych kilkadziesiąt lat temu.

$\mathrm{Z}$ racji tego, że są to mimo wszystko udostępnienia incydentalne, warto by ten stan rzeczy zmienić. Zanim jednak dojdzie do rozpowszechnienia tychże możliwości, niewątpliwie istotną potrzebą jest wcześniejsze opracowanie instrukcji udostępniania, określającej zakres i sposoby korzystania z zasobu, a przede wszystkim dostosowanie do tego zadania pracowni naukowej.

\footnotetext{
${ }^{21}$ P. Wojciechowski, dz. cyt., s. 252.

22 Zob. H. Nowak, dz. cyt., s. 206.
} 
W przedłożonym opracowaniu przedstawiłam historię i zasób archiwum Pracowni Dialektologicznej UAM. Omówiłam również organizację i zasady funkcjonowania tej placówki oraz zwróciłam uwagę na jej potrzeby.

Powyższy opis wyraźnie wskazuje, jak wiele należy jeszcze zrobić w celu ochrony zasobu oraz popularyzacji archiwum przy Pracowni Dialektologicznej UAM.

\section{Bibliografia}

Atlas jezzyka i kultury ludowej Wielkopolski, t. I-VI, pod red. Z. Sobierajskiego i J. Burszty, Wrocław [i in.] 1979-1991; t. VII-XI, pod red. Z. Sobierajskiego, Wrocław- Poznań 1992-2005.

Borowska N., Powstanie i rozwój Zakładu Fonograficznego U.P., „Biuletyn Fonograficzny” 1953, z. 1, s. 7-18.

Naczelna Dyrekcja Archiwów Państwowych, Zasady postępowania z materiałami archiwalnymi. Ochrona zasobu archiwalnego, www.archiwa.gov.pl/images/docs/Zasady_Postepowania_ NL_2011_1.pdf (dostęp 25 kwietnia 2016).

Nowak H., Od Archiwum Fonograficznego do Zakładu Dialektologii Polskiej Uniwersytetu im. Adama Mickiewicza w Poznaniu, [w:] Gwary dziś, t. 1, Metodologia badań, pod red. J. Sierociuka, Poznań 2001, s. 201-212.

Pątek K., Dokumentacja audiowizualna i mikrofilmowanie w archiwach państwowych, [w:] Technika archiwalna w XX wieku, pod red. S. Sierpowskiego i J. Wiśniewskiego, Poznań 2001, s. 27-46.

Sierociuk J., Poznańskie archiwum dialektologiczne. Zasób nagrań fonograficznych, opracowanie, [w:] Dziedzictwo audiowizualne w warsztacie badawczym historyka i procesie dydaktycznym, pod red. R. Reczka, Poznań 2015.

Sobierajski Z, Dialekty polskie i folklor z różnych regionów, Poznań 1991.

Sobierajski Z, Polskie teksty gwarowe z ilustracja dźwiękowa, cz. I-IV, Poznań 1959-1964.

Sobierajski Z, Nowak H., Hasiuk M., Tematyka nagrań gwarowych i etnograficznych z lat 1965-1969. Katalog taśmoteki Zakładu Dialektologii Polskiej Uniwersytetu im. A. Mickiewicza w Poznaniu. Część VII, „Slavia Occidentalis” 1989/1990, r. 46/47, s. 113-140.

Sobierajski Z, Nowak H., Tematyka nagrań gwarowych i etnograficznych z lat 1965-1969. Katalog taśmoteki Zakładu Dialektologii Polskiej Uniwersytetu im. A. Mickiewicza w Poznaniu. Część VI, „Slavia Occidentalis" 1988, r. 45, s. 113-140.

Sobierajski Z., Borowska N., Katalog płytoteki Zakładu Fonograficznego Uniwersytetu Poznańskiego, „Biuletyn Fonograficzny” 1953, z. 1, s. 84-105.

Sobierajski Z., Fonograficzne utrwalanie dialektów polskich w Poznaniu (Z działalności Pracowni Archiwizacji Gwar Uniwersytetu im. Adama Mickiewicza w Poznaniu), „Slavia. Časopis pro slovanskou filologii" 1963 (XXXII), seš. 1, s. 115-122.

Sobierajski Z., Katalog ptytoteki Zakładu Fonograficznego UAM, „Biuletyn Fonograficzny” 1957, z. 2, s. 81-109.

Sobierajski Z., Na jubileusz Profesora Henryka Nowaka "Slavia Occidentali” 2002, r. 59, s. 7-13.

Sobierajski Z., Nowak H., Katalog ptytoteki i taśmoteki Pracowni Archiwizacji Gwar UAM III, „Biuletyn Fonograficzny" 1961, z. 4, s. 59-96.

Sobierajski Z., Nowak H., Katalog taśmoteki Pracowni Archiwizacji Gwar Uniwersytetu im. A. Mickiewicza w Poznaniu IV, „Biuletyn Fonograficzny” 1965, z. 7, s. 103-147.

Sobierajski Z., Profesor Ludwik Zabrocki a metoda fonograficzna w dialektologii, „Sprawozdania Poznańskiego Towarzystwa Przyjaciół Nauk", nr 95, Wydział Filologiczno-Filozoficzny Poznań 1979, s. 41-46. 
Sobierajski Z., Profesor Ludwikk Zabrocki (1907-1977) a archiwizacja dialektów w Poznaniu, [w:] Linguam amicabilem facere LUDOVICO ZABROCKI in memoriat, red. J. Bańczerowski, T. Zgółka, Poznań 1999, s. 17-22.

Sobierajski Z., Skoczylas-Stawska H., Nowak H., Tematyka nagrań gwarowych i etnograficznych z lat 1965-1969. Katalog taśmoteki Zakładu Dialektologii Polskiej Uniwersytetu im. A. Mickiewicza w Poznaniu. Część V, „Slavia Occidentalis” 1982, r. 39, s. 163-184.

Sobierajski Z., Z perspektywy ćwierćwiecza - akcja nagrywania dialektów w Poznaniu w latach 1946-1969, „Biuletyn Fonograficzny” 1971, r. XII, s. 165-168.

Wojciechowski P., Przechowywanie i konserwacja akt, [w:] Metodyka pracy archiwalnej, pod red. S. Nawrockiego i S. Sierpowskiego, Poznań 2004, s. 244-255.

Zabrocki L., Archiwum Fonograficzne Instytutu Zachodnio-stowiańskiego Uniwersytetu Poznańskiego, „Slavia Occidentalis” 1948, r. 19, s. 515-517.

Justyna Kobus

\title{
Archiwum Pracowni Dialektologicznej Uniwersytetu im. Adama Mickiewicza w Poznaniu - historia, organizacja, działalność
}

\begin{abstract}
Streszczenie
W artykule zostało scharakteryzowane archiwum Pracowni Dialektologicznej UAM. Autorka opisała dzieje, działalność i potrzeby dziś nieformalnej komórki. Z artykułu można się także dowiedzieć, jakim zasobem fonograficznym dysponuje Pracownia oraz jakie towarzyszą temu zasobowi dokumenty papierowe i aparatura techniczna. W artykule jest również mowa o zbiorach bibliotecznych i etnograficznych Pracowni Dialektologicznej.
\end{abstract}

Słowa kluczowe: archiwum fonograficzne, dialektologia, fonoteka, dokumentacja papierowa, aparatura techniczna

\section{The archive of the Dialectology Workshop at the Adam Mickiewicz University in Poznań - history, organization, activities}

\begin{abstract}
The article discusses the archive of the Dialectology Workshop at the Adam Mickiewicz University in Poznań. The author describes the history, activities and needs of this unit, which currently operates informally. The article also provides information concerning the phonographical collection of the workshop, its paper documents, and the technical equipment available in the workshop, as well as its library and ethnographic collection.
\end{abstract}

Keywords: phonographical collection, dialectology, record library, paper documentation, technical equipment 